the author, when writing of the 13 th and 14 th years of Muhammad Shāh, states the then year to be the 28th of the reign (1158-9 H.); and on fol. $1,132 a$ he tells us that on the 26th Shawwal of the 25th year (1155 H.) he lost his infant son, Chaman L'al (also known as Madan L‘al), whereas Rāe Khūshhāl Chand had died on the 6th Muharram, nine months before that date.

Thus it seems impossible that the Khūshhāl Chand, author of the Nädir-uz-Zamãni, was the man of that name who died on the 6th Muharram, 1155 H.

February 3, 1898.

William Irvine.

\title{
5. A Malay Parallel to the Culla-Paduma-Jātaka.
}

Dear Sir,-May I be allowed to observe that the modern version which appeared in the October number of the J.R.A.S. (1897, pp. 85̃-857) follows very closely the story of the untrue woman, as told in the well-known fable of the Pañcatantra, iv, 13 ; in fact, in one or two points it throws light on the somewhat concise ancient narrative (thus the words sãpi kuțumbena samam pratidinam kalaham kurvānã are, as it were, illustrated by the phrase "so fair was she, that all the women of her family envied her"). About the other Asiatic and European forms which this tale underwent by its migration from East to West, see Benfey's masterwork, I, $\$ 186$. I only wish to add that the same story, with but slight variations (easily to be accounted for), has found its way among the Malays, like so many other tales of the same origin, which are now extant in the Malay Kalilah dan Daminah. A translation of this version will appear in the next volume (XI) of the Giornale della Societa Asiatica Italiana; the text is to be found also in Seidel's "Grammatik der malayischen Sprache," pp. 99-110.

Florence.

P. E. Pavolini.

February 8, 1898. 